\section{MAGDALENA GRAF}

Uniwersytet im. Adama Mickiewicza w Poznaniu, Polska https://orcid.org/0000-0002-0540-355X
Copyright and License: Copyright by Instytut Języka Polskiego PAN, Kraków 2021. This article is published under the terms of the Creative Commons Attribution - NoDerivatives 4.0 International (CC BY- ND 4.0) License (https:// creativecommons.org/licenses/by-nd/4.0/legalcode.pl).

\title{
CIALO W SIECI - (CYBER)ŚWIAT OSÓB Z ZABURZENIAMI ODŻYWIANIA W KONTEKŚCIE DYSKURSU SOMATYCZNEGO
}

Słowa kluczowe: dyskurs somatyczny, zaburzenia odżywiania, ED, socjologia ciała, socjolekt.

\section{STRESZCZENIE}

Przedmiotem omówienia jest językowy obraz ciała u osób z zaburzeniami odżywiania, które komunikują się za pośrednictwem internetu. Analiza dotyczy języka i stylu blogów i mikroblogów prowadzonych w latach 2012-2020 przez osoby (najczęściej młode kobiety) utożsamiające się z ruchem pro-Ana i pro-Mia. Wskazano najistotniejsze przemiany zachodzące $\mathrm{w}$ tej cyberwspólnocie, $\mathrm{m}$.in. przechodzenie od somatycznego wykluczenia, poprzez neutralizację ciała (body neutrality), po jego akceptację (body acceptance). Szczupłość, nawet nadmierna, jest dziś w tym kontekście często interpretowana nie jako zaburzenie (choroba), ale jako synonim zdrowego, odpowiedzialnego stylu życia. Celem analiz, oprócz uaktualnienia ustaleń językoznawców oraz badaczy reprezentujących inne dyscypliny (zwłaszcza psychologów i socjologów piszących o zaburzeniach odżywiania) są odtworzenie relacji między medialnym (konstruowanym) i odczuwanym (będącym efektem praktyk samowykluczających) obrazem ciała oraz obserwacja mechanizmów językowych, które budują i pozwalają utrzymać poczucie wspólnoty osób ze spektrum ED. Autorka, omawiająca podejmowane zagadnienia, łączy podejście językoznawcze z ustaleniami z zakresu kulturoznawstwa i socjologii, ze szczególnym uwzględnieniem badań z zakresu socjologii ciała. Przedmiotem obserwacji są leksykalne i onimiczne konteksty, w których uwidacznia się stosunek osób z zaburzeniami odżywiania do ciała, zwłaszcza w aspekcie jego fragmentaryzacji i przekształcania. Te ustalenia wpisują się w szerszy kontekst związany z przenikaniem się (sprzecznych) dyskursów: dyskursu diety oraz tzw. ciałopozytywności (anty-body shaming), czyli zaakceptowania swojego naturalnego ciała.

Zagadnienia związane z problemami osób z zaburzeniami odżywiania (ED - eating disorders) nie są tematem nowym - powstało już wiele prac opisujących możliwe przyczyny powstania tych zaburzeń i metody terapii, a przy tym ujmujących te zagadnienia $\mathrm{z}$ różnorodnych perspektyw poznawczych. Jak zauważa Bogusław Skowronek (2012, 285-286):

Dzisiaj kategorie jedzenia oraz szczupłego bądź otyłego ciała stanowią odzwierciedlenie wyraźnych rygorów ideologicznych. Jedzenie i ciało stały się obecnie mocnymi konstruktami społecznymi, represyjnie 
„zarządzanymi” przez dyskursy światopoglądowe. Pojawiły się kategorie, mocno motywowane ideologiczne: wegetarianizmu, „zdrowej żywności”, permanentnej diety, ćwiczeń gimnastycznych oraz fitness. Szczupłość (zwłaszcza) kobiecej figury stała się dla cywilizacji zachodniej indeksem sukcesu, samokontroli i nowoczesności, zaś otyłość interpretuje się jako stygmat choroby, pospolitości lub niskiej klasy społecznej. [...] Represyjna wizja figury, zwłaszcza u osób z zachwianym poczuciem tożsamości cielesnej, często skutkuje różnymi zaburzeniami odżywiania na tle psychologicznym - anoreksją, ortoreksją czy bulimią. Choroby te są jednak niczym innym, jak tylko derywatami obecnej sytuacji kulturowej, stanowią efekt działania dominujących dyskursów.

Z myślą o przeglądzie zagadnień związanych z interdyscyplinarnymi badaniami nad kulturą jedzenia należy zauważyć, że posiłek i nasz stosunek do niego stanowią istotne odzwierciedlenie globalnych zmian zachodzących w kulturze, mających wpływ na indywidualne biografie. Jedzenie ma realny, ale również symboliczny, psychologiczny, ekonomiczny czy nawet magiczny wymiar. To nie tylko zaspokajanie głodu, lecz także budowanie bezpiecznej więzi z otoczeniem, potwierdzanie poczucia bezpieczeństwa (np. redukowanie lęków czy stresu), uwodzenie, okazywanie troski, doświadczanie przyjemności. Odmowa spożywania posiłków (np. strajk głodowy) może się wiązać z wyrażaniem niezgody na obowiązujące reguły lub na hierarchię panującą w grupie (np. rodzinie). Posiłek jest też interpretowany jako jeden ze sposobów definiowania kobiecości - dotyczy to zarówno jego przygotowania, jak i spożywania, ma również związek ze stereotypowym rozróżnieniem męskich i kobiecych potraw. Rytuał wspólnych posiłków jest sygnałem przynależności do wspólnoty - ich celebrowanie, rytm i powtarzalność dają poczucie stabilności. I odwrotnie - odmowa udziału w tym rytuale (np. niedzielnym obiedzie) jest próbą zaznaczenia indywidualności. Pojawia się ona często w sytuacjach, w których jedzenie łączy się poczuciem tożsamości religijnej, a etapem pośrednim może być wprowadzanie własnych zwyczajów (rytuałów). Wreszcie - pożywienie jest symbolem naszego statusu społecznego, odzwierciedla preferowany sposób spędzania wolnego czasu, definiuje dokonywane wybory tożsamościowe. Identyfikuje nas jako osoby przynależące do określonego kręgu kulturowego, religijnego, etnicznego. (Józefik 2014, 60-68; Skowronek 2012). Wiąże się z nim również pojęcie tabu pokarmowego, obserwowanego w niemal wszystkich kulturach (Laskowska-Otwinowska 2012, 121).

Prezentowany artykuł jest poświęcony językowym obrazom ciała u osób z zaburzeniami odżywiania, komunikujących się za pośrednictwem internetu, zwłaszcza utożsamiających się z ruchem pro-Ana i pro-Mia ${ }^{1}$, ale także - choć w mniejszym zakresie - Anonimowych Żarłoków/Jedzenioholików czy osób z ortoreksją. Badania mają charakter jakościowy - zastosowano m.in. obserwację, analizę warstwy onimicznej oraz elementy analizy stylistycznej tekstów. Przedmiotem uwagi stały się również elementy wizualne blogów. Obserwację ukierunkowano na źródła internetowe, takie jak fora

\footnotetext{
${ }^{1} \mathrm{Na}$ marginesie głównych rozważań sygnalizuję różne formy zapisu: wielką (wskazujący odniesienia onimiczne obecne w tych nazwach) oraz z małą literą (wskazujący na terminologiczny charakter określenia). W opracowaniu konsekwentnie stosuję pierwszy wariant, ale w cytowanych pracach innych badaczy pozostawiam oryginalny zapis.
} 
(najczęściej zamknięte dla niezalogowanych użytkowników), blogi i mikroblogi z lat 2012-20212. Są to zarówno aktywne, jak i nieaktywne już blogi (dotyczy to zwłaszcza starszych „pamiętników odchudzania”), prowadzone na platformach blog.onet.pl, blogspot.com, pinger.pl, tumblr.com, worldpress.com. Celem analiz, poza uaktualnieniem i weryfikacją ustaleń badaczy reprezentujących inne dyscypliny (np. psychologię), było odtworzenie relacji między medialnym (konstruowanym) a odczuwanym obrazem ciała, jak również - obserwacja mechanizmów językowych budujących poczucie wspólnoty. Kontekstem uzupełniającym stały się rozpoznania z zakresu socjologii ciała - w tym aspekcie uwagę zwracam przede wszystkim na zagadnienia związane z przeobrażaniem (modyfikowaniem) ciała.

\section{JAK ZACZĘLYŚCIE PRZYGODĘ Z ANĄ? CZY MACIE ZAMIAR KIEDYŚ Z TYM SKOŃCZYĆ? ${ }^{3}$}

Pierwsze opisane medycznie przypadki jadłowstrętu, często interpretowanego jako przejaw histerii, pochodzą z XIX wieku. Zaburzenia odżywiania jako skutek niewydolności przysadki mózgowej omówiono w 1914 roku, natomiast w latach 50. powszechnie uznano psychologiczne podstawy źródeł anoreksji (Józefik 2014; Ziółkowska 2009), choć w polskim piśmiennictwie, np. w podręcznikach psychiatrii, nie poświęcano jej zbyt wiele miejsca (Kubat 2012, 133-138). Natomiast bulimię jako chorobę opisano w 1979 roku, zauważono również, że to zaburzenie pojawia się później niż anoreksja i przeważnie dotyka osób między 18. a 25. rokiem życia (Wronka i Jezierska-Kazberuk 2011, 102). Współczesne badania, stanowiące odpowiedź na znaczny wzrost zachorowań notowany od lat 90 . XX wieku, są prowadzone m.in. w ramach tzw. dyskursu diety i odwołują się do ustaleń z zakresu medycyny, psychologii i psychiatrii, pedagogiki, socjologii oraz kulturoznawstwa (np. w obszarze antropologicznych badań nad codziennością). Spośród wielu interesujących obserwacji warto przywołać tezę, w myśl której ograniczanie jedzenia w przeszłości wiązało się zazwyczaj z nakazami religijnymi, natomiast współcześnie ma związek z kulturą nadmiaru (Ziółkowska 2009, 27; Laskowska-Otwinowska 2012, 127) ${ }^{5}$.

\footnotetext{
${ }^{2}$ Różnice między poszczególnymi gatunkami szczegółowo omawia Przemysław Szews (2013).

${ }^{3}$ Funkcję śródtytułów pełnią cytaty zaczerpnięte z analizowanych blogów. Wykaz blogów poddanych analizie zamieszczam na końcu tekstu, choć ze względy na ich efemeryczny charakter oraz brak identyfikującego tytułu (którego funkcję pełnią liczne hasztagi dołączone do wpisów) nie podaję pełnego wykazu analizowanych mikroblogów.

${ }^{4}$ Jak podaje Katarzyna Kubat: „Pierwsze wzmianki o świadomym ograniczaniu pokarmów odnajdujemy w żywotach świętych. Wedle przekazów [...] św. Katarzyna ze Sieny żywiła się jedną łyżką ziół dziennie i prowokowała wymioty, gdy zmuszono ją do spożycia czegoś więcej [...]. Wczesne przypadki głodzenia, określane przez XVIII-wiecznych medyków mianem anorexia mirabilis, miały wyrażać wstręt do ciała oraz jego biologicznych funkcji” (Kubat 2012, 133-134).

${ }^{5}$ Do połowy XX wieku w psychologicznych (medycznych) opisach anoreksji podkreślano negatywny fizyczny aspekt głodzenia, czyli wyniszczenie ciała (a w konsekwencji - śmierć). Dopiero na przełomie lat 80. i 90. pojawiły się opisy mówiące o poczuciu fizycznej atrakcyjności szczupłych osób. Badania włoskich psychiatrów dowodzą, że: „zaburzenia jedzenia nie są obserwowane w czasach ogólnej biedy
} 
Analizy prowadzone w ramach różnego typu dyskursów mogą także - w obszarze dyskursu somatycznego - stać się przedmiotem refleksji językoznawczej. Z uwagi na specyfikę badań dyskursywnych przyjmuję w niniejszym artykule szeroką perspektywę obserwacji i w opisie faktów językowych obecnych w interpretowanych tekstach uwzględniam ustalenia badaczy innych dyscyplin i wiążę je z kontekstem społecznym ${ }^{6}$. Odmienne postępowanie badawcze reprezentuje m.in. opracowanie Adrianny Seniów, oparte na badaniach korpusologicznych - autorka skupia się w nim na słowotwórczym aspekcie opisu nowych derywatów z członem -reksja, w tym nazw zaburzeń odżywiania (m.in. anoreksji i ortoreksji, czyli przywiązywania zbyt dużej uwagi do zdrowego sposobu odżywiania) oraz ich produktywności. Jak wskazuje autorka, leksem anoreksja jest notowany w polszczyźnie od 1995 roku, a kolejne określenia z tego pola semantycznego, np. bigoreksja czy ortoreksja, pojawiły się w języku polskim w już w XXI wieku (Seniów 2018, 294) ${ }^{7}$.

Warto w tym miejscu przywołać również rozpoznania Magdaleny Kamińskiej, poświęcone przyczynom powstawania zaburzeń odżywiania, założeniom ruchu pro-Ana oraz charakterystyce tej społeczności ${ }^{8}$. Wskazany tekst pochodzi z 2013 roku, przez co część hipotez straciła już na aktualności. Dotyczy to m.in. uznania pro-ana za wyrażenie o charakterze szyfrującym czy odniesienia do - wskazywanych w amerykańskim piśmiennictwie - czterech typów uczestnictwa w ruchu (Kamińska 2013, 196, 202). Współcześnie charakter szyfrujący mogą mieć hasztagi ('słowa kluczowe') ${ }^{9}$ o prymarnej funkcji kamuflującej, jak \#motylki w brzuchu czy \#waniliowemleko. Są to jednak sytuacje wyjątkowe wobec dosłowności hasztagów pełniących funkcję etykiety, które

i głodu, odnotowuje się wzrost zachorowalności na nie w społeczeństwach, które osiągnęły określony poziom dobrobytu" (Palazzoli 1985 za: Kubat 2012, 141).

${ }^{6}$ Zob.: ,[P]ytania o kształt komunikacji językowej w mediach audiowizualnych muszą być ściśle powiązane z szerokim spektrum zagadnień społeczno-kulturowych [...]. Analizowanie dyskursów medialnych wyłącznie jako struktur werbalnych, bez wskazanych zależności kontekstowych, pozwala jedynie na diagnozę symptomów, a nie na wskazanie czynników w sposób decydujący zmieniających kształt komunikacji werbalnej w mediach". Zgodnie z koncepcją Normana Fairclougha wyróżnia się trzy etapy krytycznej analizy dyskursu: opis, interpretację oraz wyjaśnianie (Wilk 2007, 62).

${ }^{7}$ Na podstawie analizy danych z Korpusu Języka Polskiego autorka wskazuje istnienie odrębnych leksemów szczegółowo charakteryzujących typ zaburzenia, np. brideoreksja ('obsesyjne odchudzanie się przed ślubem') czy manoreksja ('anoreksja mężczyzn'). Przykładem nowszych derywatów z tego pola są m.in. mamoreksja/pregoreksja ('odchudzanie się w czasie ciąży'); także megareksja i fatoreksja (przeciwieństwa anoreksji, 'dążenie do uzyskania jak największej masy ciała'). To słownictwo ma zakres ograniczony do dyskursów specjalistycznych i nie pojawia się w komunikacji osób z zaburzeniami odżywiania.

${ }^{8}$ Podobny charakter ma opracowanie Agnieszki Chruścikowskiej z 2016 roku, w którym odnajdziemy $\mathrm{m}$.in. informacje o wieku autorek - w czasie prowadzonych badań najliczniejszą grupę stanowiły osoby w wieku 16 lat, najstarsze autorki blogów pro-ana miały ok. 20 lat (Chruścikowska 2016, 311). Inaczej niż kilka lat temu, dziś blogerki nie chcą być całkowicie anonimowe i - chociaż stosują nicki - dzielą się informacjami o tym, co studiują, czym zajmują się zawodowo, jakie są ich zainteresowania i pasje.

${ }^{9}$ Anna Kapuścińska (2018, 153-155) wymienia następujące funkcje hasztagów: pragmatyczną, ludyczną, fatyczną, emotywną, poznawczą oraz konatywną. Badaczka sygnalizuje też płynność granic poszczególnych funkcji. 
bezpośrednio sygnalizują temat wpisów i w ten sposób służą kategoryzowaniu wiadomości: \#motylki any; \#lekka jak motyl; \#gruba świnia; \#motylki; \#będę motylkiem; \#anorektyczki; \#nie chce jeść; \#chude jest piękne itp. ${ }^{10}$ Niemniej przywołany tekst stanowi bardzo ważne ogniwo w opisie przemian, jakie zachodzą w (cyber)świecie osób z ED (zwłaszcza pro-Ana i pro-Mia) ${ }^{11}$. Autorka opracowania zauważa m.in. istotną odmienność psychologicznych i społecznych podstaw obu typów zaburzeń - na stronach prowadzonych przez osoby chore na bulimię obserwowano niskie poczucie własnej wartości, samoocenę uzależnioną od opinii innych, a także wygórowane ambicje połączone z brakiem życiowych sukcesów i perspektyw. Natomiast przekazy medialne tworzone przez zwolenniczki ruchu pro-Ana są zdominowane przez

tematy kontroli, poczucia sukcesu, perfekcji, izolacji, [...] radzenia sobie [...]. Anoreksja jest przez nie utożsamiana z wolnym wyborem, wolnością, niezależnością, szlachetnością, pięknem i doskonałością (Kamińska 2013, 197).

Dzisiejsze obserwacje pozwalają wysunąć hipotezę o znacznym stopniu heterogeniczności tej przestrzeni - myślę tu zarówno o wzajemnych interferencjach poszczególnych dyskursów, jak i o socjologicznym aspekcie wynikającym z faktu, że wiele osób prowadzących blogi przyznaje się otwarcie do obu typów zaburzeń (w skrajnych przypadkach połączonych z samookaleczaniem, depresją i kompulsywnym objadaniem się). Dlatego możemy bez trudu odnaleźć wpisy ilustrujące przenikanie dyskursów:

Czuję się źle z aną na ramieniu. Wymawiam sobie, że to dziecinne tak się niszczyć, zastanawiam się co mną tym razem kieruję: rzeczywista chęć schudnięcia czy znowu chęć zwrócenia na siebie uwagi i potrzeba opieki ze strony innych? Może i to i to? Powtarzam sobie, że jak znowu wpadnę w silne zaburzenia odżywiania to znowu z nich wyjdę. Tylko dobrze wiem, że ja nigdy z nich nie wyszłam. Bo wychodząc z anoreksji wpadłam w drugi biegun - BED (z ang. Binge [sic!] Eating Disorder), czyli kompulsywne objadanie się. To dalej są zaburzenia odżywiania. [Koktajlowa]

${ }^{10}$ Te hasztagi pełnią funkcję typową dla tego elementu komunikacji sieciowej, jednak ich dosłowność pozwala suponować, że autorki tych blogów jeszcze nie zetknęły się z zewnętrzną cenzurą i zamknięciem bloga - stąd brak sygnałów autocenzury widocznych np. w tradycyjnych blogach: „Ten blog został mi już usunięty dwukrotnie! Za pierwszym razem nie przyszło mi oczywiście do głowy aby podać adres do nowego itd. Zapewne jak ktoś zgłosi go po raz trzeci to już go nie odzyskam. Dlatego też stworzyłam nowego bloga. Dużo bardziej ocenzurowanego. Oby tego też nie usunęli..." [Kreator]. Interesującym obszarem autocenzury jest tytuł blogu - autorki często decydują się na nowy ideonim, który nie sygnalizuje jednoznacznie treści, ponieważ liczą, że blog nie zostanie usunięty, np.: „Porażka nie wchodzi w rachubę. Kontynuacja bloga ‘o18kilomniej' i wielu innych usuwanych na przestrzeni lat 2012-2018. Chciałabym znów znaleźć dla siebie miejsce w tej społeczności i mam nadzieję, że ten blog pozwoli mi na poznanie Was i spotykanie się z Wami w naszym wirtualnym azylu jakim jest blogger" [Porażka].

${ }^{11}$ Zob:. „Używane w celu szyfrowania nazw dwóch najpowszechniejszych schorzeń ze spektrum ED skróty «Ana» i «Mia» stosowane są przez osoby identyfikujące się z tą ideologią w taki sposób, jakby były imionami przyjaciółek" (Kamińska 2013, 196). 


\section{W SUMIE W MOIM ŻYCIU NIE DZIEJE SIE NIC CIEKAWEGO, A PRZYNAJMNIEJ NIC TAKIEGO[,] O CZYM CHCIALABYM TU NAPISAĆ, WIĘC DO PUBLIKOWANIA ZOSTAJĄ TYLKO BILANSE. DAJE MI TO OGROMNĄ MOTYWACJE, LICZE TE WSZYSTKIE KALORIE, BO NIE CHCE ZAWIEŚĆ ANI SIEBIE, ANI WAS}

Jak zauważa Karolina Olejnik, pojęcie wspólnoty ma w badaniach z zakresu socjologii wyidealizowany charakter - odsyła do „zbiorowości społecznej, w której jednostki cechują się tendencją do spontanicznych, emocjonalnych i autotelicznych relacji z innymi”. W rzeczywistości - dodaje badaczka - istnieje wiele odmiennych form wspólnot, także wirtualnych (Olejnik 2005, 221) $)^{12}$. Ich powstanie było warunkowane m.in. zmianami w obrębie obowiązujących modeli komunikacji: transmisji (czyli komunikowaniu jednostronnym, „mówieniu do kogoś”) i interakcji (czyli wymianie poglądów, ,rozmawianiu z kimś”). Zdaniem badaczy komunikacja wirtualna ma charakter zapośredniczony, a przejawia się w dwóch odmianach: komunikowaniu quasi-bezpośrednim i niebezpośrednim. W skrajnym przypadku zachodzi także w sytuacji braku realnego kontaktu, gdy informacja jest przekazywana za pomocą znaków i symboli, które „stwarzają możliwość wymiany wiedzy, realizowania projektów i rozpoznawania rzeczywistości” (Fearing za: Olejnik 2005, 228). Wśród najważniejszych wyznaczników wspólnoty wirtualnej wymienia się: wspólnotę języka, kultury, wiary; zaangażowanie członków; istnienie granic definiujących, kto jest, a kto nie jest jej członkiem; zestaw behawioralnych norm i reguł; grupową samoidentyfikację (Olejnik 2005, 231). Sygnalizowane założenia mają płynny charakter - stąd wynikają trudności w jednoznacznym zdefiniowaniu pojęcia wspólnoty wirtualnej, sygnalizowane przez badaczkę. Co więcej, nawet obserwacje tej samej społeczności prowadzone na osi czasu pozwalają ukazać przemiany zachodzące w tym obszarze (np. stopniowe zanikanie fizycznych rytuałów włączających w środowisku pro-Ana).

Badania wskazują, że internet jest podstawową przestrzenią, w której funkcjonują grupy pro-ED (Strzelecki i in. 2010; Wronka i Jezierska-Kazberuk 2011). Pozwala to m.in. na

kreowanie enklaw: wspólnot online złożonych ze społecznie izolowanych lub stygmatyzowanych jednostek, które w warunkach względnego bezpieczeństwa wynikającego z możliwości anonimowej komunikacji dzielą się doświadczeniami i przemyśleniami (Kamińska 2013, 197-200)13.

Warto zauważyć zróżnicowanie przestrzeni komunikacyjnej, w której funkcjonują osoby ze spektrum ED - o ile zwolenniczki ruchu pro-Ana i pro-Mia (a także - analogicznych ruchów anty-) od początku funkcjonują niemal wyłącznie w cyberprzestrzeni, o tyle grupy skupiające osoby z innymi typami zaburzeń (np. Anonimowi Żarłocy/Jedzenioholicy)

\footnotetext{
${ }^{12} \mathrm{~W}$ opracowaniach wskazuje się następujące cechy wspólnoty: odczuwanie więzi psychicznej z pozostałymi członkami, powstanie na gruncie związków obiektywnie uwarunkowanych, zaspokajanie potrzeb członków wspólnoty, stosunki oparte na przyjaźni, współdziałaniu, sąsiedztwie, pokrewieństwie (za: Olejnik 2005, 221-223).

${ }^{13}$ Zainteresowanie lingwistów komunikacją w przestrzeni wirtualnej w wyczerpujący sposób omawia w swym opracowaniu Małgorzata Kita (2016).
} 
preferują kontakt bezpośredni, rzadziej są aktywni w internecie. Jednak rozwój i właściwości komunikacji wirtualnej (pozwalającej np. na zachowanie całkowitej anonimowości) oraz wpływ pozawirtualnej rzeczywistości (m.in. pandemia koronawirusa) ${ }^{14}$ sprawiły, że także te społeczności stają się w coraz większym stopniu obecne w Sieci (Talarczyk i Nitsch 2010, 76-78) ${ }^{15}$. Na podstawie ustaleń badaczy oraz własnych obserwacjach Magdalena Kamińska zauważyła, że środowisko anorektyczek i bulimiczek - pomimo wspólnych celów i łączącej je więzi emocjonalnej - jest niespójne pod względem przekonań na temat zaburzeń odżywiania, zauważalna też była wzajemna niechęć osób utożsamiających się z jednym z ruchów. (Kamińska 2013, 203). Niemal dekadę później trudno już tak jednoznacznie wytyczyć granicę między zjawiskami. Można jednak dostrzec ich hierarchizację, uwarunkowaną ,atrakcyjnością”, łatwością w stosowaniu zasad przy obietnicy osiągnięcia podobnych celów. Wciąż znaczną grupę osób tworzących tę społeczność stanowią tzw. wannabes, czyli osoby aspirujące, jednak odnajdujemy też powracających do Any oraz osoby, które stosują rygorystyczne zasady ruchu, ponieważ traktują je jako jeden z rodzajów diety, sposób na utratę znacznej nadwagi. Co ciekawe - poza jednostkowymi wyjątkami (np. „Ważysz $60 \mathrm{~kg}$ i twierdzisz że jesteś pro ana? Wiesz w ogóle, co to znaczy?") - nie spotykają się one z krytyką środowiska, którego ekskluzywny charakter jest przez badaczy wskazywany jako jedna z konstytutywnych cech tej cyberspołeczności. Nie jest to także społeczność wyłącznie kobieca - współcześnie anoreksja jest problemem, z którym mierzą się też młodzi mężczyźni. Warto również zauważyć, że o ile wcześniej „Blogi pro-ana prowadzone dłużej niż przez kilka miesięcy należą do rzadkości. Ich treść składa się głównie z próśb o rady [...] a także litanii obelg pod własnym adresem" (Kamińska 2013, 206), o tyle dziś, jeśli nie nastąpiło zamknięcie bloga przez administratora, możemy bez trudu odnaleźć strony, na których rozbudowane tematycznie wpisy są prowadzone dłużej niż przez rok (w najstarszym czynnym blogu poddanym analizie pierwszy wpis pochodzi z roku 2012).

Podobnie jak na początku XXI wieku w USA, tak w ostatnich latach w Polsce zaczęto w związku ze wzrostem zainteresowania ruchami pro-ED - zamykać blogi tworzone przez osoby identyfikujące się z pro-Ana ${ }^{16}$. W efekcie autorki bądź tworzyły nowe blogi, bądź przenosiły się na inne platformy komunikacyjne, jak Instagram czy Tumblr (co niosło ze sobą widoczne przemiany w zakresie językowego aspektu tej komunikacji, przede

\footnotetext{
${ }^{14}$ Warto w tym miejscu zwrócić uwagę na niewielki poziom zainteresowania aktualnymi zjawiskami wpisy dotyczące pandemii koronawirusa pojawiają się niemal wyłącznie wtedy, gdy choruje autorka blogu lub gdy ograniczenie mobilności ma negatywny wpływ na utrzymanie reżimu dietetycznego. Sporadycznie pojawiają się wpisy dotyczące sytuacji społeczno-politycznej, np. protestów w ramach Strajku Kobiet.

${ }^{15}$ Forum jako przestrzeń komunikacyjna cieszy się dziś coraz mniejszym zainteresowaniem, a to zjawisko dotknęło również (najczęściej zamknięte, dostępne po zalogowaniu) fora poświęcone pro-Ana, co widać w statystykach wejść.

${ }^{16}$ „No i stało się. Zablokowali mi bloga. Odwołałam się, blog został przywrócony, ale na jak długo? [...] Swoją drogą paradoks polega na tym, że jak pisałam o głodówkach i załamaniu, to nikt się nie czepiał, a jak napisałam posta, który w założeniu miał odstraszać od ED i ustrzec od popadania w nie, to bach! Blokada. Wiem, że to logarytm przeszukuje posty, żaden nerd nie siedzi przed monitorem i złośliwie nie blokuje blogów po przeczytaniu milionów postów, ale i tak jest to paradoks" [Znikam].
} 
wszystkim skróconą warstwę tekstową, często ograniczoną do krótkich komunikatów uzupełnianych tekstami multimedialnymi ${ }^{17}$ ). Często więc pozornie „nowe” blogi są po prostu kontynuacją stron zablokowanych wcześniej ${ }^{18}$ - zarówno w starszej, jak i w nowszej wersji zawierają one obszerne (nieraz bardzo, jak np. w przypadku blogów Fuzzybrain czy Kreator wymarzonego życia) wpisy nieograniczające się wyłącznie do bilansów czy relacji z dziennego ważenia - tworzenie bloga to w tych przypadkach nie tylko zapis z „dzienniczka odchudzania”, lecz także forma autoterapii. Warto też zauważyć, że nowe blogi są zakładane również przez osoby powracające do ruchu po dłuższej nieobecności:

Nie sądziłam, że po tylu latach wrócę do pisania bloga. Uznałam jednak, że będzie to dla mnie mała odskocznia. Pamiętam, gdy w 2008-2009 roku zaczynałam pod pseudonimem GreenTea. Te lata i parę kolejnych to był wybuch blogów o tematyce ed. Ta społeczność była ogromna, a ja młoda i głupia. Wiele się zmieniło przez 13 lat, ale pewne aspekty zostają z Nami na zawsze. [Patrz]

lub:

Szczerze, nie wierzyłam, że zostanę tu na dłużej niż kilka dni. Każda wcześniejsza próba trwała moment, kiedy tu wracałam. Nie było z kim tu pisać, nic mi to nie dawało. Tym razem stał się cud, bo okazało się, że jest tu nas tak dużo i dostałam wsparcie, zainteresowanie. Mogę tu zostawić swoje problemy. [Moja]

a także:

Chciałam się z wami przywitać, ponieważ wracam tu kolejny raz i za każdym razem widzę nowe twarze. A może wcale nie takie nowe, bo miałyśmy możliwość poznać się na innych blogach, pod innymi nickami. Zakładam bloga, ponieważ szukam motywacji, by utrzymać się swojego postanowienia - schudnąć. Dużo. Spędziłam na tym odchudzaniu sporą część swojego życia, a mimo to nadal nie osiągnęłam tej perfekcji, jaką sobie postawiłam za cel te 9 lat temu. Tym razem się uda, w końcu tego potrzebuję. [Kawa]

\section{NIE BYLO MNIE TYDZIEŃ, WIĘC JAK NA MNIE TO BARDZO DLUGA PRZERWA OD BLOGA, ALE WLAŚCIWIE NIE MIALAM O CZYM PISAĆ}

Warto w tym miejscu skierować uwagę ku ,tradycyjnej” socjolingwistyce (Grabias 2019, 84-92, 99-118), której dorobek w wyczerpujący sposób prezentuje m.in. Magdalena

\footnotetext{
${ }^{17}$ Istotną cechą mikroblogu jako gatunku jest zwięzłość i kondensacja przekazu oraz sposób rozpowszechniania informacji, polegający na ich „przekazywaniu dalej”. Jak zauważa Przemysław Szews: „Istotą mikroblogów, a jednocześnie tym, co odróżnia je od blogów, jest bardzo szybki przepływ informacji, a także możliwość ich kategoryzowania i porządkowania oraz selekcji otrzymywanych informacji (użytkownik sam decyduje, od kogo i skąd otrzymuje informacje)" (Szews 2013, 278).

${ }^{18}$ Przykładowo: „Kontynuacja bloga «przeklinam cię ciało» (2014-2016), który został zablokowany. Kiedyś podałam swoje imię ale od dziś jestem po prostu Fat Pig PS. Jest to blog o charakterze pamiętnikarskim. Nie promuje anoreksji ani niezdrowej diety. Każdy odwiedzający wchodzi tu na własną odpowiedzialność. Waga wyjściowa 10.05.2021 - 109,3 kg” [Because] lub „No i zaczynamy wszystko od nowa. Nie, nie dlatego, że zawaliłam, a dlatego, że usunięto mi bloga. Ale co tam! Założyłam nowy. Osoby, które weszły tu pierwszy raz mogą być zdezorientowane, że pierwsza notka jest czterdziestą pierwszą notką, ale to dlatego, że na poprzednim blogu skończyłam na numerze czterdzieści” [Koktajlowa].
} 
Smoleń-Wawrzusiszyn (2016). Autorka konstatuje, że także dziś, w dobie badań nad językiem wspólnot funkcjonujących głównie w przestrzeni wirtualnej, założenia metodologiczne dyscypliny nadal znajdują zastosowanie. Trzeba jednak dopowiedzieć, że zmieniający się paradygmat wymusza modyfikację narzędzi interpretacyjnych i zmianę hierarchii ich ważności - np. upodrzędnia znaczenie analiz statystycznych. Niemniej komunikacja $\mathrm{w}$ środowisku osób $\mathrm{z}$ zaburzeniami odżywiania $\mathrm{w}$ znakomitym stopniu realizuje cztery funkcje, wskazane przez Stanisława Grabiasa: jednoczącą, odróżniającą, nadawania prestiżu oraz interpretacyjną $(2019,118)$. Badacze socjolektów wskazują też relację komunikacji w sieci wobec kontaktów językowych zachodzących w przestrzeni realnej - jak ma to miejsce np. w typologii zaproponowanej przez Martę Juzę (za: Smoleń-Wawrzusiszyn 2016, 194). Z myślą o obszarze poddanym obserwacji mówimy przede wszystkim o ostatniej kategorii, czyli o relacjach tworzących się i kontynuowanych w przestrzeni wirtualnej:

Z perspektywy lingwistyki wspólnoty wirtualne tworzą się i funkcjonują na takich samych zasadach, jak społeczności w rzeczywistości realnej - ich podstawą jest jakiś rodzaj więzi, mają jedynie inne, wirtualne [...] przyporządkowanie [...]. Dla wielu grup społecznych obecność w sieci jest współcześnie wręcz obligatoryjna i w tym wirtualnym obszarze aktywności komunikacyjnej włączanie się do określonych wspólnot jest pożądanym (czy oczekiwanym) standardem zachowań (Smoleń-Wawrzusiszyn 2016, 195).

Badacze piszący o językowych wykładnikach polszczyzny w sieci wskazują takie parametry, jak: odejście od linearności i uporządkowania przyczynowo-skutkowego; brak założonego przesłania odautorskiego; eliptyczność i skrótowość komunikatu; łączenie kodów werbalnych z ikonicznymi; eklektyzm piśmienności i oralności; kolokwializacja i wulgaryzacja wypowiedzi; liczne neologizmy i zapożyczenia anglojęzyczne; odejście od norm poprawnościowych (Ogonowska i Skowronek 2005, 299-303). Przywołane tu, ogólne (a więc i płynne) cechy języka internetu mogą - na potrzeby analizy komunikacji określonej cyberspołeczności - podlegać znacznym modyfikacjom. Bogusław Skowronek $(2013,236)$ sygnalizuje ten problem:

[T]rudność pisania o zjawiskach (nie tylko werbalnych) przestrzeni Internetu bierze się stąd, iż są to zjawiska w swej dynamice dalece wyprzedzające wszelki zamykający naukowo opis. Raz - z powodu swej nieogarnialnej liczby przejawów, dwa - z powodu ciągłej zmienności pojawiających się form (warto tu wspomnieć o koncepcji cyberdyskursywności Martina Jacobsona).

Zatem uwagę zwraca fakt, że choć otrzymujemy teksty o różnym poziomie organizacji przyczynowo-skutkowej, to jednak niektóre z wpisów okazują się wewnętrznie uporządkowane pod względem kompozycyjnym, z zaznaczonym wyraźnie celem wypowiedzi, nieraz są to również bardzo rozbudowane formy realizujące różne wzorce gatunkowe. Zmianie może też podlegać hierarchia potrzeb - np. w przypadku opisywanej grupy niezmiernie istotną rolę odgrywa potrzeba wsparcia ${ }^{19}$. Dlatego bez trudu możemy

\footnotetext{
${ }^{19}$ Jak zauważa M. Smoleń-Wawrzusiszyn: „Odwołując się do przedstawionej typologii wspólnot sieciowych opartej na kryterium potrzeb, cyberspołeczności uwzględnione w moich badaniach scharakteryzowałabym
} 
zauważyć, że przeniesienie aktywności na inne medium (np. Instagram) nie spełnia oczekiwań autorek, które same często „milkną” po kilku wpisach, co jest - moim zdaniem - wynikiem braku poczucia wsparcia ze strony innych Motylków. Warto zauważyć, że mówimy tu o społeczności, która - mimo pozornej wspólnotowości - jest zróżnicowania ze względu na wiek (z ruchem identyfikują się zarówno uczące się nastolatki, jak i osoby studiujące, często kilka kierunków, a także pracujące zawodowo żony i matki), staż (aspirujący, początkujący, zaawansowani, wracający), sytuację społeczną (np. pochodzenie z rodziny niepełnej lub mierzącej się z problemami alkoholowymi) i materialną (materialna zależność od rodziców lub samodzielność finansowa), wykształcenie, miejsce zamieszkania, wreszcie - płeć (choć w przestrzeni tej wciąż dominują kobiety ${ }^{20}$ ). Znajduje to odzwierciedlenie w warstwie językowej - od zróżnicowania stylistycznego (pragmatycznego) wypowiedzi i zasobu stosowanej leksyki (także jej poprawności) po długość wypowiedzeń i złożoność struktur składniowych. Widać to choćby w poniższych, przykładowych wpisach, których tematem jest dzienny bilans:

\begin{abstract}
Staram się też największe posiłki zjadać rano oraz nie jeść niczego ciężkiego po godzinie 18. No i wodaco ranek stawiam sobie na biurku półtoralitrową butlę, którą uznaję za dzienne minimum. Na szczęście ostatnio nie mam już takich problemów z piciem jak kiedyś, bez problemu pochłaniam te 1,51 i nieraz wypijam drugie tyle przed końcem dnia.

Jak prezentował się mój dzisiejszy jadłospis? W jego skład wchodziło śniadanie w formie podsmażanych na patelni (bez tłuszczu!) warzyw - pomidora, resztek papryki, połowy cebuli, trzech główek czosnku, połowy cukinii - z łyżką wegańskiego pesto oraz odrobiną bazylii i oregano. Na obiad zjadłam szklankę krupniku. Po 15 złapał mnie ogromny głód, więc „przegryzłam” pół słoiczka (ok. 60 g) wspomnianych wyżej czarnych oliwek. Na kolacje zjadłam trzy wegańskie „kiełbaski” z soi z dodatkiem mielonej papryki [Podróż]
\end{abstract}

lub:

$29 / 06[-] 1 / 15$

Kupiłam sobie dziś kilka herbatek odchudzających i jakieś tabletki na metabolizm. Zobaczymy co to będzie.

jako te, w których podstawową potrzebą budującą więzi między członkami grupy jest wspólnotowość zainteresowań. Natomiast inne potrzeby - wsparcia, rozrywki i tym podobne - traktuję jako wtórne i jako takie albo mogą się pojawić w trakcie funkcjonowania grupy, albo też nie" $(2016,203)$. Tymczasem bez trudu odnaleźć możemy wpisy typu:

Tak w ogóle jest was już ponad 2 tysiące to jest niesamowite! Nawet nie wiecie jak się cieszę i jaką cholerną motywacje i siłę do działania mi to daje! Coś cudownego aż nie mogę uwierzyć i się popłakałam ze szczęścia! to jest najszczęśliwszy dzień jaki dotąd miałam. Oj na prawdę już dawno się tak nie cieszyłam jak dziecko! jak teraz!! Haha niesamowite :D DZIĘKUJĘ WAM ZA TO, ŻE JESTEŚCIE!!!!! [Zagubiona].

${ }^{20}$ Zob.: ,W licznych doniesieniach z badań to kobiety stanowią grupę, w której poziom satysfakcji z własnego ciała jest obniżony. Niezależnie od wieku, kobiety częściej od mężczyzn doświadczają na przestrzeni życia negatywnych uczuć w obszarze doświadczania własnego ciała: są niezadowolone z wagi ciała, obawiają się przytycia, są zaabsorbowane traceniem na wadze [...]. Spostrzegają one swoje ciało jako obiekt i kontrolują jego wygląd w kontekście atrakcyjności. Częściej ujawniają zaburzony stosunek do własnego ciała, przejawiający się w różnej psychopatologii, zwłaszcza anoreksji i bulimii psychicznej” (Kobierecka 2012, 384). 
Bilans:

serek wiejski -221

truskawki -100

wafle ryżowe -59

chrupki kukurydziane -268

razem: 648/650 zaliczone

trzymajcie się chudo, dobranoc :* [Porażka]

$\mathrm{Z}$ drugiej strony - bez trudu odnajdujemy wskazane przez autorów cechy: łączenie kodów werbalnych z ikonicznymi czy silną emocjonalizację przekazu manifestującą się w jego wulgaryzacji, np.:

Znowu potrzebuję tej jebanej diety jak lekarstwa, które później znowu będzie mnie zatruwać. Ostatnim razem dało mi to ulgę na początku by przejść przez problemy, które mnie bolały, a później każdy dzień był mordęgą, wiem o tym i nie chce tego a jednocześnie tego potrzebuję. [Moja]

czy:

Dzisiaj [...] poprosiłam chłopaka by zrobił mi zdj. włosów od tyłu. Zobaczyłam swoją dupę, a raczej jakiś prostokąt. Ja pierdole, jak można się tak zapuścić. Nawet nie mam słów do siebie w tej chwili. Nie da się na to patrzeć. Nic dziwnego, że unikałam lustra. Dobrze, że nie mogę wyjść z domu, bo spaliłabym się ze wstydu. Brzydzę się sobą. [Moja]

Interesującą odrębnością współczesnych blogów wpisujących się w nurt pro-Ana jest to, że niektóre z nich tworzą osoby ze znaczną nadwagą, które do prowadzenia „dzienniczków odchudzana" wykorzystują schemat stosowany na blogach pro-ED, np.:

jestem grubą i tłustą świnią! Ważę 118 kg i chce mi się płakać jak na siebie patrzę. Nie czuję się atrakcyjna, wszędzie mam cellulit i rozstępy. Zaniedbałam się. Ale koniec z tym. Od dzisiaj robię sobie wyzwanie 31 dni bez pepsi i fastfoodów. Oczywiście nie chcę pić żadnych słodzonych napojów.

Chcę więcej ćwiczyć i codziennie przynajmniej pół godziny na platformie wibrującej.

Taki jest plan. We wrześniu waga ma pokazać liczbę dwucyfrową. [Wzlecieć]

Powyższy cytat skłania do interesujących obserwacji - oto potrzeba komunikacji w nowej sytuacji życiowej, trzeci ze wskazanych przez Tomasza Piekota aspektów zmian językowych, prowadzi do zjawiska, w którym ,grupa osób połączona silną więzią i wspólnym działaniem zaczyna odczuwać konieczność mówienia swoim własnym językiem” (Piekot 2008, 7). Przemiany społeczno-kulturowe doprowadziły do sytuacji, w której zainteresowanie badaczy socjolektów przenosi się z języka grup zawodowych ku komunikacji w środowiskach rówieśniczych, towarzyskich, grupach skupionych wokół określonej tematyki. Zgodnie z typologią zaproponowaną przez Piekota, można komunikację osób z zaburzeniami odżywiania uznać za szczególny przykład socjolektu kontestacyjnego. Zdaniem badacza: 
Odmiany tego typu powstają w środowiskach zamkniętych, istniejących na obrzeżach społeczeństwa. Podstawową cechą organizującą takie społeczności jest negatywny stosunek do otaczającej rzeczywistości, przejawiający się świadomym buntem, prowokacją oraz negowaniem wszelkich norm i konwencji społecznego życia. Prowadzi to do stworzenia alternatywnych i obligatoryjnych zachowań, wyselekcjonowanych i wykreowanych przez system ról społecznych oraz wartości charakterystycznych dla danej zbiorowości. [...]. Doprowadza to do stworzenia mikrospołeczeństwa, w którym jakość życia i komunikacji określają grupowe wartości, obligatoryjne zachowania, represyjność, a także - narzucające określony światopogląd - autostereotypy (Piekot 2008, 35).

Komunikacja w takich mikrospołecznościach charakteryzuje się wysokim poziomem emocjonalności, istotną rolę odgrywa też w niej rytuał - rozumiany tu jako zarówno określony zbiór zachowań, jak i rytuał językowy ${ }^{21}$. Rytualizacja przekazu dotyczy nie tylko sfery interpersonalnych relacji zachodzących między członkami cyberwspólnoty (np. w postaci zwrotów adresatywnych, np. Drogie Motylki, Kruszynki czy pożegnań typu trzymajcie się chudo), lecz także autoprezentacji (np. „Butterfly wannabe. Kluska dążąca do celu, jakim jest UGW wynosząca 50 kilogramów” lub „Jestem Trufla. Młoda wyglądem, stara duszą. GRUBA. Chcę być perfekcyjna. Chcę być piękna") i ramy tekstowej wpisów, niebędącej wyłącznie efektem szablonu zapożyczonego z internetowej biblioteki (Talarczyk i Nitsch 2010). Można postawić supozycję, że kontrola i perfekcja odnoszące się do dyscyplinowania ciała dotyczą również sposobów prowadzenia wpisów, np. stałego, konsekwentnie realizowanego schematu części inicjalnej, co można zaobserwować po porównaniu - przykładowo wpisów z 2018 i 2021 roku, pochodzących z tego samego bloga:

002 Nic mi nie wychodzi...

Dalej te jebane $54 \mathrm{~kg}$... nic nie schodzi. Ale patrzmy na plusy - nie przytyłam.

oraz:

098 Momenty zawahania

Waga: 51,5 kg Hej! Tak, nadal tutaj jestem mimo, że piszę trochę rzadziej, ale po prostu nie mam teraz zbytnio na to czasu. [...]

099 Cel: $49 \mathrm{~kg}$

Waga: $51,2 \mathrm{~kg}$ Od nowego roku spadła zaledwie o $0,4 \mathrm{~kg}$. [...]

100 Winter

\footnotetext{
${ }^{21}$ Rolę rytuału w komunikacji wyczerpująco omawia Beata Drabik (2010, 13-33). Autorka, na podstawie obszernej literatury przedmiotu, to zjawisko definiuje jako ,zachowanie komunikacyjne, werbalne i/lub niewerbalne, mające charakter symboliczny, podejmowane przez członków danego społeczeństwa w określonych sytuacjach interakcyjnych z uwagi na funkcje społeczne, które pełni, oraz z uwagi na określone, przewidywalne cele, które pozwala osiągnąć, i często ze względu na wymóg norm społecznych, cechujące się skonwencjonalizowaniem treści, stabilnością i przewidywalnością formy, powtarzalnością występowania oraz przejawiające tendencję do automatyzacji i zatarcia się sensu".
} 
Waga: 50,7 kg To jest mój setny wpis wow. Nie sądziłam, że dam radę to zrobić, a jednak dałam [...]. [Be like]

W mniejszym zakresie omawiane zjawisko daje się zaobserwować w nowszych mediach, np. wpisach zamieszczanych na platformach Tumblr, Instagram czy Pinterest, sprawiających wrażenie przypadkowych notatek, tworzonych ad hoc. Od tekstów z klasycznych blogów różni je też relacja tekstu do obrazu - w skrajnych przypadkach możemy odnaleźć mikroblogi, w których zapisy stanowią wyłącznie formy wizualne (emotikony, obrazy, kolaże, zdjęcia, teledyski i fragmenty filmów). Wyraźnie widać też ich osadzenie w kulturze cytatu - stąd liczne zapożyczenia ze stron innych Motylków. Warto tu zwrócić uwagę na prośby o reblogowanie ('pokazanie na własnym blogu wpisu innej osoby’), typu: „Bardzo proszę aby osóbki z aktywnymi blogami o anie reblogowały tego posta bo brakuje mi thinspo i cytacików ${ }^{22}$ '), powielanie tych samych schematów lub infografik przedstawiających kaloryczność produktów, „sprawdzone” zestawy ćwiczeń, wreszcie - swoista iteracja thinspiracji (wyjątkowo są to zdjęcia autorskie najczęściej obrazy kopiowane z Sieci bez podania ich źródła). Warto zwrócić uwagę na poszerzający się słownik leksyki skupionej wokół pól wyrazowych podstawowych dla tego dyskursu: jedzenie/pożywienie (jako całość i jako tworzące je składniki), kaloryczność potraw, ciało i jego (wybrane) części, także słownictwo odnoszące się do sfery emocji, związane z potrzebą (samo)kontroli, samotnością, izolacją. Można też wskazać słownictwo swoiste, o socjolektalnie ograniczonym zakresie użycia. Przede wszystkim są to literowce odsyłające do stosowanych diet, np. IF (Intermittend Fasting); SGD (Skinny Girl Diet); SPD (Skiny Pink Diet); BJD (Blue Jeans Diet) itp. - uwagę zwraca ich perswazyjność: diety nimi identyfikowane mają bardzo restrykcyjny charakter (w skrajnych przypadkach zaleca się przyjmowanie około 600 kalorii dziennie, minimalna wartość dozwolonych kalorii to 200; część diet polega na stosowaniu regularnych postów), jednak identyfikujące je nazwy charakteryzują się pozytywną wartością konotacyjną i asocjacyjną, np. Cosy sweater diet; The Snow White Diet; Sweet, Tiny Body Diet; Dieta Świnki Balbinki; Cinderella’s Diet. Także w tym dyskursie możemy odnaleźć przejawy mody leksykalnej - np. rodzimą głodówkę zastępuje fast lub fasting, dzienniczek odchudzania to coraz częściej dietbook lub foodbook. Ten leksykon można uzupełnić o PPM (Podstawowa Przemiana Materii - 'najniższy poziom przemiany energetycznej, która zachodzi w organizmie człowieka, uznawany za maksymalną granicę dozwolonych w ciągu dnia kalorii'); bing (Bing Eeating Disorder - 'kompulsywne objadanie się'); napad, bilans/bilanse (funkcjonujące również w stałych wyrażeniach typu: otwarcie bilansu, niski/wysoki bilans); thinspiracje/thinspiration/ thinspo lub fatspiracje/fatspiration (czyli motywujące zdjęcia bardzo szczupłych lub chorobliwie otyłych osób); okienko żywieniowe ('wyznaczona pora dnia, w czasie której można sięgnąć po jedzenie’). Podobnie jak w polszczyźnie ogólnej, także tu możemy

\footnotetext{
${ }^{22}$ Chodzi tu o tzw. pro thin quotes - przypominające mantrę motywacyjne teksty typu: „If I eat something, I eat everything so I eat nothing".
} 
zauważyć działanie tendencji do ekonomiczności przekazu - stąd skrócone, potoczne formy, np. thinspo; niezdrowe comfy food (comfort food 'jedzenie na pocieszenie, o wartości sentymentalnej'); obcinanie kaloryki ('obniżanie wartości kalorycznej potraw'); kompuls/kompulsy ('kompulsywne objadanie się lub wymiotowanie'); tipy (dzielić się tipami 'dzielić się radami'), np.:

Jestem bardzo zła na siebie

Wkurwiona

Znowu miałam binge [sic!] eating day i zjadłam tyle, że to żart. Od dziś zacznę wstawiać bilanse z dnia, może to mnie jakoś zmotywuje. Ogółem staram się trzymać limitu 600, nie robię żadnej konkretnej diety. Przynajmniej jak na razie.

BILANS

Zjedzone: W CHUJ

Spalone: spacer, ok 500kcal. [My sweet]

Obserwacja językowego aspektu komunikacji pozwala wskazać podstawowe wyznaczniki interakcji skoncentrowanej wokół zaburzeń odżywiania i obszary pozostające we wzajemnej relacji, jak: ciało, jego dyscyplinowanie i fragmentaryzacja, rytuał (zwłaszcza jako czynnik służący niwelowaniu lub osłabieniu poczucia lęku oraz element budujący poczucie wspólnoty - chodzi tu zarówno o rytuały wspólnoty komunikacyjnej, jak i o akty indywidualne), silna emocjonalność przekazu (przejawiająca się zwłaszcza w jego wulgaryzacji), medykalizacja, praktyki autowykluczające. Obserwujemy też niski poziom metaforyzacji języka. Ponieważ opis wszystkich wskazanych elementów przekracza ramy artykułu, skupię się na wybranych aspektach, których nie poruszali autorzy innych opracowań. Warto zatem zwrócić uwagę na warstwę onimiczną i elementy quasi-onimiczne - nazwy forów i blogów, tytuły wpisów na blogach, nicki (pseudonimy) użytkowników, stosowane etykiety i hasztagi. Są one pierwszym, leksykalnym sygnałem udostępnianych treści, a poza informacyjną pełnią również funkcje dodatkowe: perswazyjną, impresywną, niekiedy - poetycką. Reprezentują różny poziom dosłowności bądź metaforyczności i wpisują się we wskazane pola tematyczne:

- zaburzenia odżywiania: mojkompuls; jedzeniocholiczka; Nic nie smakuje lepiej niż chudość; Lekka na granicy egzystencji; \#kości;

- stosunek do jedzenia / jedzenie jako rytuał: Okruszki w pościeli; Kto nakruszyt na stót; Niewiele na talerzu; po-głodzie-do-celu; Nie jestem głodna; Głodne myśli; Jak się je?; zaduzokal; Żyję po to by nie jeść; \#nie chce jeść;

- przemiana (najczęściej z zastosowaniem metafory drogi/podróży): My journey to be skinny; My Way to Heaven; Życie droga marzeń; Pro Ana w drodze do doskonałości;

- samotność, problemy fizyczne i psychiczne, brak wsparcia najbliższych: Zagubiona we wtasnym Ciele; Powracający natóg; Mój kościsty demon; upadly-czarny-aniol; samotna grubaska; \#ból; \#cierpienie; \#depresja; \#stany emocjonalne; 
\#samotność; \#rodzina; \#jestem beznadziejna; \#nie jest ok; \#jestem sama; \#myśli samobójcze;

- $\quad$ wypaczony (negatywny) obraz własnego ciała (widoczny przede wszystkim w osobowych identyfikatorach): fat Katy; Thinfat; słaba; Grubaja; Smutna Grubaska; gruba_ruda; wielorybek wrócit; świnka wróciła; Trufla; Nigdy nie jesteś zbyt chuda; \#grubaska; \#gruba szmata; \#za gruba; \#gruba świnia;

- ciało (i jego dyscyplinowanie): królestwo-samokontroli; prochuda; skinny body; Anonimowa Perfekcjonistka; \#samokontrola; \#perfekcja;

- $\quad$ strach przez brakiem efektów: podróż w nieznane; może tym razem dam radę?; \#brak kontroli;

- $\quad$ nadzieja na osiągnięcie założonego celu: Kreator wymarzonego życia; grubasdocelu; wolna-jak-ptak-lekka-jak-wiatr; tym razem się uda; moje dażenie do perfekcji; My appetite for perfection; W perfekcyjnym świecie; Motyl; Kiedyś musi się udać; wytrwam; ciagle walczę; \#chce być motylkiem; \#będę idealna;

- detabuizacja śmierci: porcelanowy-motyl-śmierci; Byt sobie szkielet; Lubię umierać powoli; Tańcząc nad przepaścia; umierajaca dusza; Znikam już mnie nie ma. Najobszerniejszy zbiór stanowią określenia zawierające leksykalne odniesienia do ED, zwłaszcza do anoreksji - My Motylki; Dom porcelanowych motyli (fora); NienazwAna; Czarny Motyl; Zagubiony Motylek; Pro ana pamiętnik motylka; Pro ana is my dream; Porcelain Butterfly project; Kruchy motylek; gtupi motylek; gruby-motylek; Wieloryb lekki jak motylek; Nastolatka lekka jak motylek; Wzlecieć niczym motyl; Pamiętnik Panny A.; MiaBlood; hungrybutterfly; be like Ana; Ana is perfect; porcelanowa; upadty motylek.

Analiza materiału onimicznego, zwłaszcza nicków i hasztagów, pozwala dostrzec pewną prawidłowość - oto jesteśmy świadkami swoistej zmiany pokoleniowej (i związanej z nią zmiany preferencji dotyczących platformy komunikacyjnej) - o ile „starsze” uczestniczki tej wspólnoty (także ze względu na wiek) pozostają wierne „tradycyjnym” przestrzeniom komunikacyjnym, a ich nicki pełnią często funkcję identyfikacyjną (np. Królewna Śnieżka, Ariela, Danny, Koktajlowa), o tyle osoby młodsze, zwłaszcza aspirujące, preferują nowe media. Widać to zwłaszcza w hasztagach, których dosłowność przypomina cechy obserwowane przez badaczy w początkowych fazach popularności ruchów pro-ED, zwłaszcza pro-Ana: \#pro ania; \#lekka jak motyl; \#lekka jak piórko; \#motylek; \#motylki; \#pragnę chudości; \#chcę widzieć kości itp. Dlatego - w najogólniejszym zarysie - realizują one cechy wskazywane niemal dekadę temu przez Magdalenę Kamińską (skupienie na sobie, wpisy ograniczone do bilansów, silna wulgaryzacja tekstów i rezygnacja z prowadzenia bloga po kilku wpisach). W warstwie semantycznej odsyłają one przede wszystkim do - wyrażonej za pośrednictwem języka - relacji do ciała/cielesności, zarówno własnej, jak i prezentowanej w przekazach medialnych dołączonych do wpisów. Jednak stwierdzenie, że osoby ze spektrum ED mają negatywny stosunek do ciała, byłoby tu zbyt daleko idącym uproszczeniem - tego rodzaju zagadnienia można wszak interpretować w szerszym kontekście współczesnego dyskursu somatycznego. 


\section{MENTALNIE JESTEM CHUDZINĄ, FIZYCZNIE - PRZECIĘTNĄ DZIEWCZYNĄ W NORMIE. DYSONANS, DĄŻĘ DO JEGO REDUKCJI, CHCE BY MOJE CIALO STALO SIE MANIFESTEM UMYSLU}

„Tak jak dla średniowiecznych mniszek pokarm prowadził do zanieczyszczenia duszy, kierując ją ku cielesności, dla anorektyczek pokarm jest zanieczyszczeniem organizmu" stwierdza Adam Buczkowski (2005, 302). Współcześnie - dodaje badacz - anoreksję można interpretować jako

przejaw jednego z elementów cywilizowania ciała - indywidualizacji oraz związanej z nią tendencji do zarządzania ciałem. Ciało staje się tutaj narzędziem władzy skierowanej przeciwko sobie $(2005,304)$.

Uwidacznia się tu pewien paradoks: oto - wskazane przez Buczkowskiego - dążenie do całkowitej kontroli nad ciałem i jego indywidualizacja w wirtualnym świecie Any dzieją się niemal publicznie. Konieczność podzielenia się doświadczeniami, obecność komentujących obserwatorów, poczucie wspólnotowości stają się niezbędnymi elementami komunikacji w ramach analizowanego dyskursu. Interesującą perspektywę budują tu badania Arthura Franka, który zakładał m.in., że ludzie doświadczają istnienia swojego ciała i zarazem są przez nie ograniczani - co jest wynikiem relacji społecznych. W jego pracach obecne jest pojęcie cielesnych technik społecznych, a centrum tej koncepcji stanowią pytania o działanie poprzez ciało w takich obszarach, jak: kontrola, odczuwanie pożądania, relacja do innych ciał oraz relacja do samego siebie (za: Buczkowski 2005, 16). W kontekście omawianej problematyki uwagę zwracają dwie skrajne koncepcje. Zatem ciało kontrolowane to ciało poddawane dyscyplinie ${ }^{23}$, natomiast $\mathrm{w}$ relacji do samego siebie środkami działania okazują się komunikacja i poznanie, a modelem użycia - wspólne poglądy i rytuały:

Ciało kontrolowane poprzez dyscyplinę dąży do ukrycia swej przypadkowości i uczynienia go przewidywalnym poprzez różnego rodzaju praktyki reglamentacyjne. Ciało dyscyplinowane jest odosobnione i izolowane, oddziela się je [...] od własnej powierzchni i odczuwania oraz empatii w stosunku do innych ciał (Buczkowski 2005, 17).

Spojrzenie z perspektywy socjologii ciała (np. Shilling 2019; Jakubowska 2009) pozwala je interpretować m.in. jako składnik ponowoczesnej tożsamości, element gry interakcyjnej, jako kapitał, towar i obiekt własności, miejsce kontroli społecznej, odbiorcę wrażeń, narzędzie przyjemności i źródło cierpienia oraz źródło wiedzy i doświadczenia. W mniejszym lub większym stopniu wszystkie wskazane aspekty dyskursu somatycznego możemy dostrzec w analizowanych tekstach.

\footnotetext{
${ }^{23}$ Zagadnienia związane z dyscyplinowaniem ciała kierują uwagę ku rozpoznaniom Michela Foucaulta i praktykom wskazanym przez niego w książce pt. Nadzorować i karać. Narodziny więzienia $(2009,132-133)$.
} 


\section{NA CHWILĘ OBECNĄ NIE MOGĘ NA SIEBIE PATRZEĆ. NA CALYM CIELE WIDZĘ TLUSZCZ. WYLĄCZNE ZWALY TLUSZCZU. KILKA DNI TEMU PISAŁAM COŚ O PLASKIM BRZUCHU. MUSIALAM BYĆ NAĆPANA}

Jak zauważa Honorata Jakubowska, współcześnie obserwujemy ewolucję sposobów czytania cielesności i interpretowania praktyk somatycznych. W ich konsekwencji zmieniła się hierarchia atrybutów cielesności, spośród których na plan pierwszy wysuwają się przeksztatcalność oraz rozczłonkowanie. Dlatego praktyki cielesne są przede wszystkim wynikiem negowania własnej, naturalnej cielesności, a osłabienie kontekstu biologicznego automatycznie podnosi rangę „czytania” ciała w kontekście jego jednostkowej i społecznej (re)konstrukcji (Jakubowska 2009, 90-92; Kubat 2012, 142):

Wobec możliwości, a często i kulturowego/społecznego „przymusu” (re)konstruowania cielesności, ciało biologiczne jest traktowane jako pierwotny tekst, który musi być wiecznie przeredagowywany, poprawiany i uzdatniany pod presją adekwatności (Jakubowska 2009, 92).

Zdaniem autorki nasza codzienność charakteryzuje się subiektywną nieobecnością ciała (absent body), a jego pojawienie się, zarówno w sferze fizycznej, jak i psychicznej, jest zazwyczaj związane z jego patologiczną formą, np.:

Pamiętaj, że chcesz być piękna, piękne są widoczne obojczyki, zaznaczone żebra, widoczne kości biodrowe. To jest piękne. Obrzydliwe są oponki na biodrach, wylewający się brzuch, cellulit na udach i obwisła skóra na ramionach. [Ana]

Ten rodzaj uobecnienia domagającego się uwagi ciała powoduje naszą alienację. W badaniach socjologów pojawiają się więc pytania o relacje ciała i tożsamości (np. Giddens 2002; Rudnicki 2013), o zmiany, jakie w tych relacjach zachodzą w momencie modyfikacji ciała (np. Bauman 2008). Wskazują oni, że następuje zrównanie tożsamości i cielesności, czego efektem jest m.in. potrzeba kontrolowania własnego wizerunku (a tym samym - tożsamości):

Nie jestem w stanie powiedzieć kiedy to się zaczęło. Chyba od zawsze ciągnęło mnie do zniszczenia. Tylko wyrażałam to w inny sposób. Jak teraz sobie myślę, wydaje mi się, że zawsze potrafiłam znaleźć w sobie coś do zmienienia. W twarzy, ciele, charakterze. Zawsze istniał jakiś element, który mi nie pasował. Nie wiedziałam tylko, że tak na prawdę to ja jestem tym elementem... [Wzlecieć]

Zatem ciało, jako przedmiot (i podmiot) działania, źródło praktyk uczestniczących, staje się podstawowym komponentem tożsamości. Jednak ciało, które jest nam dane, okazuje się tylko początkiem złożonego procesu przekształcania (stąd wyzyskanie w tym dyskursie metafory motyla powstającego z gąsienicy). Ciało jest projektem, który domaga się realizacji, a który nigdy nie zostanie ukończony - dotarcie do wyznaczonej granicy w sposób niemal automatyczny przekłada się na projektowanie kolejnych celów: 
Jestem... zawsze nie taka jak chcę. Walczę... o lekkość bytu. Cel: gdzieś między tym, co jest, a 0 . Wzrost: $170 \mathrm{~cm} \mathrm{Cel} \mathrm{1:} 60 \mathrm{~kg}$ Cel 2: $58 \mathrm{~kg}$ Cel 3: $56 \mathrm{~kg}$ Cel 4: $54 \mathrm{~kg}$ Cel 5: $52 \mathrm{~kg}$ Cel 6: $50 \mathrm{~kg}$ Cel 7: $49 \mathrm{~kg}$ Cel 8: 47kg Cel 9: 45kg. [Thin]

Badacze zajmujący się socjologią ciała wskazują też na pewien paradoks - nawet jeśli ciało (np. chore) znajduje się w centrum zainteresowania, to trudno jest zdać relację z jego doświadczania. Częściowe potwierdzenie tych tez odnajdujemy w analizowanych wpisach, w których najwięcej uwagi poświęca się temu, jakie ciało jest i jakie ma być, znacznie rzadziej odnajdziemy informacje o tym, co dzieje się z nim w procesie przekształcania. Można tu przywołać konstatację Honoraty Jakubowskiej, wskazującej na „trudność zdania relacji z doświadczeń własnego ciała - trudność w ujęciu słowami tego, co dzieje się z naszym ciałem, tego, w jaki sposób ciało stawia opór"24. Zdaniem badaczki doświadczanie ciała chorego, pozbawionego swoich kulturowych i społecznych znaczeń, sprowadzonego jedynie do własnej materialności i procesów fizjologicznych, pozostaje w sferze prywatnej (Jakubowska 2012, 14-16). Terapeuci zauważają, że - w zależności od fazy choroby - ED towarzyszą liczne zaburzenia somatyczne, związane m.in. z trwałymi zmianami w funkcjonowaniu niektórych narządów (Wiatrowska 2013, 280). Do rzadkości jednak należą wpisy relacjonujące tego rodzaju problemy, jak:

Nie będę Was oszukiwać - jest ciężko. W życiu. W diecie bardzo średnio. Dzisiaj ok. 1500kcal. Po prostu staram się nie mieć napadów. Jestem na środkach przeczyszczających. Nie wiem czy to forma autoagresji czy strachu przed zobaczeniem znowu na wadze 120kg. [Koktajlowa]

lub:

Powoli oswajam się z myślą o odbudowaniu mojego zrujnowanego metabolizmu. Ponoć przywrócenie go do sprawność sprzed głodówek jest nie możliwe. Takie tam niewinne konsekwencje na całe życie, w stylu tych gwiazdek pisanych na umowach małym druczkiem. [Kreator]

Obrazy zmieniającego się ciała dotyczą więc bądź sytuacji skrajnych (realizujących schemat: jesteś - chciałabyś być), bądź efektów końcowych, szczegółowo wskazanych, negatywnych (z obiektywnej perspektywy) skutków długiego stosowania restrykcyjnych diet i głodówek. W tych pierwszych, często na zasadzie antynomii, zestawia się skrajne obrazy, np. ,wylewający się tłuszcz” i „wystające kości”. W drugim przypadku odnajdujemy wpisy osób, które toczą bądź wygrały walkę z zaburzeniami odżywiania:

ED to nie instagramowe zdjęcia płaskich brzuchów i szczupłych ud w krótkich spodenkach. To ból, cierpienie i łzy. Wstyd i strach, smród i obrzydliwości ludzkiego ciała. To strach, którego nikomu nie życzę. [Znikam]

\footnotetext{
${ }^{24}$ Zob.: „Drogie ciało! Większość ludzi kompletnie nie rozumie, jak bardzo Cię nienawidzę. Cały czas odmawiam sobie jedzenia, a Ty się nie zmieniasz. Katuję się godzinami ćwiczeń, a Ty tego nie doceniasz. Nie pomagasz mi w żaden sposób, ponieważ wcale nie wyglądam lepiej. Cały czas w lustrze widzę tę samą osobę. Moja psychika momentami siada... Tysiąc przykrych komentarzy w moją stronę i miliony łez wylanych w poduszkę. Nie mogę na ciebie patrzeć”.
} 
oraz:

Wiem, to chore... ale my wszystkie tu jesteśmy chore. [...] Bo wiecie... ja też schudłam do 49 , też byłam bardzo chuda... a potem przypałętał się jakiś inny demon, demon obżarstwa. Na początku demon bulimii, potem już czystego BED. BED na przemian z Aną. Mam zdiagnozowaną przez psychiatrę [...] anoreksję bulimiczną, ale nie wiem czy to dobra diagnoza. Bo ja już nie wymiotuję, ja się nie przeczyszczam. Ja po prostu na przemian się obżeram, głodzę, potem jem niby normalnie (czyli też się trochę obżeram), a potem znowu się obżeram, głodzę i tak w kółko... Ten koszmar trwa już 15 lat... [...] Powiem tylko tyle: ja już nie wierzę, że z tego wyjdę. Ale jeśli Ty dopiero zaczynasz - odpuść. [Koktajlowa]

Jednak te działania są z góry skazane na niepowodzenie - w przypadku choroby krytyka własnego wyglądu wiąże się z zniekształconym obrazem ciała. Zazwyczaj mówi się o błędnej ocenie jego rozmiarów, choć najnowsze badania wskazują, że zachodzi ona głównie u osób zdrowych, natomiast w anoreksji mamy do czynienia „ze zniekształconym aspektem emocjonalnym obrazu własnego ciała”, a „osoby z restrykcyjną odmianą anoreksji w większości nie zniekształcają rozmiarów ciała, co więcej, wiedzą i akceptują to, jak wyglądają" (Cwojdzińska 2009, 107). Stąd wszelkiego typu apele o zmianę nawyków żywieniowych spotykają się z reakcją typu:

Każdy kto w tym siedzi, ma świadomość z czym to się wiąże. Autodestrukcyjna osobowość. Dla mnie w chwili obecnej nie ma znaczenia, że każdy włos na mojej głowie jest rozdwojony, że paznokcie trzyma tylko lakier, że wciąż jestem zmęczona, że mam rozwaloną wątrobę i układ trawienny jest upośledzony, że stan skóry się pogarsza, że mam wahania nastrojów... To wszystko nie ma znaczenia. [Thin]

\section{NIE O TO CHODZI W CHUDNIĘCIU, ŻEBY UMRZEĆ. JUŻ NIE}

Problematyka ciała/cielesności od dawna spotyka się z ogromnym zainteresowaniem badaczy reprezentujących różnorodne dyscypliny badań humanistycznych. W pewnym stopniu, choć przywoływano w nich te same, kanoniczne opracowania, wskazane badania były prowadzone „niezależnie” (odnotujmy choćby refleksje z zakresu językowego obrazu anoreksji w opracowaniach z zakresu psychologii, ale też wielość terminów, np. somapoetyka, dyskurs somatyczny, dyskursy cielesności) lub zdominowane przez określony typ dyskursu (np. genderowy, medyczny czy antropologiczny). Jednak wydaje się, że obecnie badacze zmierzają do integrowania tych rozpoznań, do ich konfrontowania i weryfikowania. Taką strategię przyjmuje choćby Seweryn Rudnicki (2013, 131), który zauważa:

[...] znakowy związek między ciałem a ,ja" słabnie i nabiera cech coraz dalej idącej i uświadamianej arbitralności. Ciało zaczyna funkcjonować jako symulakr, znak bez stabilnej referencji, którego zakorzenienie w rzeczywistości i powiązanie z ,ja” jest coraz słabsze. Jeśli bowiem możliwe jest względnie łatwe [...] modyfikowanie np. swojego wyglądu [...], to stabilność i wiarygodność oznaczania ,ja" przez ciało zostaje tym samym podważona. [...] Kod symulakru jest podobny do kodu uwięzienia w tym sensie, że ciało może być traktowane jako przeszkoda i ograniczenie ,ja" - w tym wypadku kluczowa jest jednak możliwość pokonania tego ograniczenia. Ciało samo w sobie nie jest 
[...] wartościowane wysoko, może być nawet dewaluowane, doceniana jest raczej możliwość jego swobodnego kształtowania.

Językowe obrazy ciała, stanowiące przedmiot moich obserwacji, są ilustracją mechanizmów (samo)wykluczających, a zarazem interesującym zaprzeczeniem tez dotyczących dyscyplinowania ciała oraz - tabuizowanych w języku (i kulturze) - obrazów ciała nieidealnego, chorego, starzejącego się. Językowe obrazy ciała osób z zaburzeniami odżywiania nie stanowią już sfery prywatnej - autorki informują w swoich blogach o zachodzącej w nich przemianie: fizycznej i emocjonalnej. Analizowane wpisy są też interesującym sygnałem zjawisk związanych z (re)konstrukcją czy modyfikacją ciała. Na przestrzeni lat, poza przemianami stricte językowymi ${ }^{25}$, nastąpiła też zmiana warstwy wizualnej (i estetycznej), zarówno w obszarze szaty graficznej analizowanych (mikro)blogów, jak i w zestawie prezentowanych thinspiracji. Coraz rzadziej są w nich ukazane obrazy dziewczyn z pozszywanymi lub pozaklejanymi ustami, okaleczonymi ciałami czy tzw. bones pictures (przerobione komputerowo fotografie ukazujące osoby w stanie skrajnego wychudzenia). Zamieszczane zdjęcia sygnalizują fascynację (zwłaszcza młodszych blogerek) kulturą mangi i gwiazdami K-Popu. Coraz częściej też pojawiają się - w funkcji antyinspiracji - zdjęcia osób chorobliwie otyłych, najczęściej pokazywanych w trakcie spożywania posiłku (to tylko wstępne obserwacje, które można potwierdzić szerszymi badaniami z wyzyskaniem narzędzi analizy multimodalnej). Zatem nie jest to ciało, o którym się milczy (por. Jaxa-Rożen 2011, 116 i n.) - przeciwnie: zarówno nienormatywna szczupłość, jak i nadmierna otyłość są na stronach poświęconych zaburzeniom odżywiania ukazywane i (auto)komentowane.

Warto zauważyć, że uobecnione ciało jest przedmiotem sprzecznych dyskursów, w ramach których - z jednej strony (np. w dyskursie diety) - mówi się o kontroli ciała, natomiast z drugiej - o tzw. ciałopozytywności, czyli o zaakceptowaniu swojego naturalnego ciała i uwolnieniu go od praktyk dyscyplinujących (anty-body shaming). W tym kontekście i anoreksja, i chorobliwa otyłość stają się skrajnymi wyrazami tych dyskursów. Pojęcie wyzwolenia ciała, obecne w dyskursie somatycznym, ma jednak charakter ambiwalentny, gdyż obok jego pozytywnych przejawów obserwujemy też zjawiska wskazujące na nowe formy opresji, a samo ciało wysuwa wobec nas coraz większe wymagania. Stajemy się współczesnymi biczownikami - odczuwamy potrzebę kontrolowania ciała, będącą swoistym substytutem świadomego życia. Jej skrajnym wyrazem są praktyki somatyczne będące udziałem osób z zaburzeniami odżywiania. Realnym efektem tej ambiwalencji jest jedno ze schorzeń obecnych w tym spektrum ortoreksja, czyli uzależnienie od zdrowego stylu życia (w tym - od zdrowej żywności). Analiza zebranego materiału pozwala zauważyć, że - w przeciwieństwie do początków funkcjonowania ruchu pro-Ana - współcześnie nie powstają już zamknięte, tajemne grupy (potwierdza to również malejąca popularność forów internetowych oraz coraz mniejsza anonimowość uczestników omawianej komunikacji). Stopniowo przemianie

\footnotetext{
${ }^{25}$ Ich najczytelniejszym efektem jest „,sms od Any”, który zastąpił formę tradycyjną: „list od Any”.
} 
ulega także współczesny dyskurs somatyczny: Od fat przez skinny do fit - to tytuł jednego z blogów, w którym niczym w soczewce skupiają się najistotniejsze zjawiska zachodzące w językowym obrazie analizowanej cyberwspólnoty - przechodzenie od somatycznego wykluczenia, poprzez neutralizację ciała (body neutrality), po jego akceptację (body acceptance). Szczupłość, nawet nadmierna, jest dziś w tym kontekście interpretowana nie jako zaburzenie (choroba), ale jako synonim zdrowego, odpowiedzialnego stylu życia. Jak zauważała już w 2005 roku Monika Frąckowiak ${ }^{26}$ :

Głodzenie się, poddawanie ciała dyscyplinującym reżimom oraz bezwzględne, kompulsywne dążenie do ściśle ustalonego ideału urody stanowi jeden z przejawów ,autodestrukcyjnej adaptacji” do rzeczywistości społecznej, której ramy wyznacza sztywno i nierealistycznie interpretowana norma perfekcjonizmu. Znamienne dla anoreksji panowanie nad ilością spożywanego pokarmu jest dla osoby chorej oznaką silnej woli, samokontroli oraz posiadania umiejętności odraczania gratyfikacji [...]. Z podobnymi mechanizmami mamy do czynienia również w przypadku pracoholizmu, kompulsywnego uprawiania sportu [...], fanatycznego wyznawania określonych idei. Dochodzi wówczas do „fetyszyzacji” lub „autonomizacji” jednej z ról społecznych oraz związanego z nią obszaru, co w oczywisty sposób zaburza funkcjonowanie w złożonym kontekście społecznym $(2005,175)$.

Warto zweryfikować te obserwacje. Zatem aby wyznaczyć pole do dalszych badań, należy zwrócić uwagę na następujące problemy:

- czy i w jakim stopniu postępują wzajemne interferencje dyskursów diety (np. w jakim stopniu osoby chore na ortoreksję będą aktywne w Sieci);

- jak w przestrzeni wirtualnej uobecniają się medialne i językowe przekazy osób utożsamiających się ze zjawiskiem anty-body shamingu (m.in. jako reakcja na strategie językowego wykluczenia);

- czy ich medium będzie blogosfera, czy raczej ta aktywność przeniesie się na media społecznościowe (jak Instagram, Snapchat czy Pinterest).

Pierwsze sygnały przemian zachodzących w tym obszarze widać już dziś27 (zob. Teler 2021). Jak zauważa Anna Teler (2021, 108), w wymiarze społecznym anty-body shaming nie tylko staje się promowaniem pozytywnego obrazu ciała (samoakceptacji), ale też

zwalnia z konieczności nieustannego odnoszenia się do społecznych standardów piękna, chorobliwego porównywania się i odczuwania wstydu, a także zwalnia z konieczności zadowolenia z ciała.

Nasuwa się pytanie, czy wobec zachodzących przemian medialnego obrazu ciała i cielesności, w mediach cyfrowych w coraz mniejszym stopniu aktywne będą osoby z zaburzeniami odżywiania, nieakceptujące swojego wyglądu - jak sygnalizuje badaczka:

\footnotetext{
${ }^{26}$ Badaczka wskazuje też, że „w społeczeństwie ponowoczesnym (informacyjnym) sieci społeczne powstające za pośrednictwem mediów elektronicznych stanowią istotny element środowiska społecznego wielu jednostek oraz wypełniają przestrzeń pomiędzy najbliższym otoczeniem mikrospołecznym (rodziną) a kontekstem makrospołecznym (społeczeństwem globalnym)" (Frąckowiak 2005, 172).

${ }^{27}$ Zob.: „Hahahah ktoś jeszcze pisze blogi o tej tematyce? jak tak sprawdziłam, to zobaczyłam może z dziesięć... EDtumblr jest dużo bardziej aktywny jednak" [Nigdy].
} 
media cyfrowe są obecnie istotną przestrzenią renegocjacji ciała ludzkiego poprzez wizualne reprezentacje promujące jego różnorodny obraz (Teler 2021, 110).

\section{ŹRÓDŁA}

9 żywotów. https://kotarabski.blogspot.com/ (10 stycznia 2021) [Kot].

Ana is perfect. Only for Butterflys. https://anabutterflyblog.wordpress.com/ (10 stycznia 2021) [Ana].

Anoreksja moje dążenie do perfekcji. http://ana-pro.blog.onet.pl/ (1 stycznia 2020) [Anoreksja].

Apetite for destruction. http://vespertine-butterfly.blogspot.com/ (10 stycznia 2021) [Apetite].

Because the pain of looking in the mirror hurts more than starving... http://max500calories.blogspot.com/ (10 stycznia 2021) [Because].

Be like Ana. https://belikeana.home.blog/ (10 stycznia 2021) [Be like].

Dark paradise. https://grub-want-fly.blogspot.com/ (10 stycznia 2021) [Dark].

Davina is shrinking. https://davinasshrinking.blogspot.com/ (10 stycznia 2021) [Davina].

Dom porcelanowych motyli. http://www.porcelanowemotyle.mojeforum.net/ (1 stycznia 2020).

DROGA DO ZDROWIA. http://nielubiebycglodna.blogspot.com/ (10 stycznia 2021) [Droga].

dyingforperfection. http://tumblr.com/ (10 stycznia 2021).

Fly like a butterfly. https://flylikeabutterfly49.blogspot.com/ (10 stycznia 2021) [Fly].

Fuzzybrain. https://fuzzybrainbutterfly.blogspot.com/ (10 stycznia 2021) [Fuzzybrain].

Głodne myśli. https://therafosa.blogspot.com/ (10 stycznia 2021) [Głodne].

Gruba Chce Być Chuda! http://grubachcebycchuda.pinger.pl/ (10 stycznia 2021) [Gruba].

hello-kiedys-bede-chuda. http://tumblr.com/ (10 stycznia 2021).

Kawa na czczo. http://kawanaczczo.home.blog (10 stycznia 2021) [Kawa].

kiedysznikne. http://tumblr.com/ (10 stycznia 2021).

Kiedyś PRO ANA. Teraz dążę by być FIT i HEALTHY. https://aniawithed.blogspot.com/ (10 stycznia 2021) [Kiedyśs].

Koktajlowa. https://fasting20hours.blogspot.com/ (10 stycznia 2021) [Koktajlowa].

Kreator wymarzonego życia. https://kreatorwymarzonegozycia.blogspot.com/ (10 stycznia 2021) [Kreator].

Kto nakruszył na stół? Forum pro-ana. http://www.proanamotyle.pun.pl/ (1 stycznia 2020).

Lekka na granicy egzystencji. https://lekkanagranicyegzystencji.blogspot.com/ (10 stycznia 2021) [Lekka].

Moja perfekcja - o tym jak niebo okazało się piekłem. http://jestem-piekna-kiedy-znikam.blogspot.com/

(10 stycznia 2021) [Moja].

Motylki pro Ana. http://butterflylife4.blogspot.com/ (1 stycznia 2020) [Motylki].

MY APPETITE FOR PERFECTION. http://appetite-for-perfection.blogspot.com/ (10 stycznia 2021) [My apetite].

My Sweet Little Nightmares. http://mysweetlittlenightmares.blogspot.com/ (10 stycznia 2021) [My Sweet]. Nastolatka lekka jak motylek. http://nastolatka-lekka-jak-motylek.blog.onet.pl/ (10 stycznia 2021) [Nastolatka]. Nie jestem głodna. http://motyleklife.blogspot.com/ (10 stycznia 2021) [Nie jestem]. nieperfekcyjna. http://tumblr.com/ (10 stycznia 2021).

Niewiele na talerzu. https://niewiele-na-talerzu.blogspot.com (10 stycznia 2021) [Niewiele].

Nigdy nie jesteś zbyt chuda nigdy-nie-jestes-zbyt-chuda. http://blog.onet.pl/ (1 stycznia 2020) [Nigdy nie]. 
Nigdy wystarczająco dobrze. http://anasgonnafixeverything.blogspot.com/ (10 stycznia 2021) [Nigdy]. Nothing tastes as good as skinny feels $\{\{i\}\}$. https://anaismy.blogspot.com/ (10 stycznia 2021) [Nothing]. Od fat przez skinny do fit. Moja Pro Ana. http://skinny-pro-ana.blogspot.com/ (10 stycznia 2021) [Od fat]. Okruszki w pościeli. http://okruszkiwposcieli.wordpress.com/ (10 stycznia 2021) [Okruszki].

Pamiętnik dietetyczny. https://mojeodzywianie.home.blog/ (10 stycznia 2021) [Pamiętnik].

Patrz ale nie dotykaj. https://aan-de-rand.blogspot.com/ (10 stycznia 2021) [Patrz].

Perfekcji iluzja... http://never-say-i-am-loser.blogspot.com/ (10 stycznia 2021) [Perfekcji]. Perfekcyjnie nieperfekcyjna. https://czerwona-niteczka.blogspot.com/ (10 stycznia 2021) [Perfekcyjnie]. Perfekcyjność. https://perfekcjajestblisko.blogspot.com/ (10 stycznia 2021) [Perfekcyjność]. Podróż w nieznane. https://beautiful-world-is-my-dream.blogspot.com/ (1 stycznia 2020) [Podróż]. Porażka nie wchodzi w rachubę. https://43kilogramy.blogspot.com/ (10 stycznia 2021) [Porażka]. Porcelain butterfly project. https://theporcelainbutterflyproject.blogspot.com/ (10 stycznia 2021) [Porcelain]. Pro ana pamiętnik motylka )))!(((. http://proanapamientnikmotylka.blogspot.com/ (10 stycznia 2021) [Pro ana]. Puszka Pandory... i inne potwory. https://puszkapandoryiinnepotwory.blogspot.com/ (10 stycznia 2021) [Puszka].

Queen of ones life. http://queenofoneslife.blogspot.com/ (10 stycznia 2021) [Queen].

Skinny obssesion. https://myrealitywithana.blogspot.com/ (10 stycznia 2021) [Skinny].

Thin Line. https://thinlineforever.blogspot.com/ (10 stycznia 2021) [Thin].

Vivere militare est. https://viveremilitareest-2020.blogspot.com/ (10 stycznia 2021) [Vivere].

Walcząc o marzenia. http://ciaglewalcze.blogspot.com/ (10 stycznia 2021) [Walcząc].

Wieloryb lekki jak motylek. http://proana-onlyfriend.blogspot.com/ (10 stycznia 2021) [Wieloryb].

Wonder Woman. https://wonderwoman2021.blogspot.com/ (10 stycznia 2021) [Wonder].

Wygrać z anoreksją. http://bycwolna.blogspot.com/ (10 stycznia 2021) [Wygrać].

Wzlecieć niczym motyl. http://niczymmotyl.blogspot.com/ (10 stycznia 2021) [Wzleceć].

Zagubiona we własnym ciele. https://butterflyproanna.blogspot.com/ (10 stycznia 2021) [Zagubiona].

Zagubiony Motylek. https://zagubionymotylek2018.blogspot.com/ (10 stycznia 2021) [Zagubiony].

Znikam już mnie nie ma. http://znikamjuzmnieniema.blogspot.com/ (10 stycznia 2021) [Znikam].

\section{BIBLIOGRAFIA}

Bauman, Z. 2008. „Ponowoczesne przygody ciała”. W Antropologia ciała. Zagadnienia i wybór tekstów, red. M. Szpakowska. Warszawa: Wydawnictwo Uniwersytetu Warszawskiego, 95-102.

Buczkowski, A. 2005. Społeczne tworzenie ciała. Płeć kulturowa i pteć biologiczna. Kraków: Universitas. Chruścikowska, A. 2016. „Charakterystyka blogów pro-ana”. Pielęgniarstwo i Zdrowie Publiczne 6 (4): 309-314.

Cwojdzińska, A. 2009. „Obraz ciała w anoreksji psychicznej”. W Ciało w kulturze i nauce, red. B. Ziółkowska, A. Cwojdzińska, i M. Chołody. Warszawa: Wydawnictwo Naukowe Scholar, 106-112.

Drabik, B. 2010. Językowe rytuaty tworzenia więzi interpersonalnej. Kraków: Wydawnictwo Uniwersytetu Jagiellońskiego.

Foucault, M. 2009. Nadzorować i karać. Narodziny więzienia. tłum. T. Komendant. Warszawa: Wydawnictwo Aletheia. 
Frąckowiak, M. 2005. „Anorexia nervosa - fenomen ponowoczesnej kultury i choroba systemu rodzinnego”. Dylematy Wspótczesnych Rodzin. Roczniki Socjologii Rodziny XVI: 171-188.

Giddens, A. 2002. Nowoczesność i tożsamość. „Ja” i społeczeństwo w epoce późnej nowoczesności. thum. A. Szulżycka. Warszawa: Wydawnictwo PWN.

Grabias, S. 2019. Język w zachowaniach społecznych. Podstawy socjolingwistyki i logopedii, wyd. 4 rozsz. Lublin: Wydawnictwo Naukowe UMCS.

Jakubowska, H. 2009. Socjologia ciała. Poznań: Wydawnictwo Naukowe UAM.

Jakubowska, H. 2012. „Ciało jako przedmiot badań socjologicznych - dylematy, pominięcia, możliwości”. Przegląd Socjologii Jakościowej 8 (2): 12-31.

Jaxa-Rożen, H. 2011. „Sztuka krytyczna jako refleksja nad estetyzacją ciała w kulturze współczesnej”. W Ciało cielesne, red. K. Konarska. Wrocław: Wydawnictwo Uniwersytetu Wrocławskiego, 115-122.

Józefik, B. 2014. Kultura, ciało, (nie)jedzenie. Terapia. Perspektywa narracyjno-konstrukcjonistyczna w zaburzeniach odżywiania. Kraków: Wydawnictwo Uniwersytetu Jagiellońskiego.

Kamińska, M. 2013. „Masz anoreksję? chcesz mieć anoreksję? to blog dla Ciebie;) Rola wannarexics w cyberśrodowiskach pro-ana”. W Nowe media i wyzwania wspótczesności, red. M. Sokołowski. Toruń: Wydawnictwo Adam Marszałek, 193-215.

Kapuścińska, A. 2018. „Kod kulturowy a nowe media na przykładzie znacznika >>\#<<”. Socjolingwistyka XXXII: $151-162$.

Kita, M. 2016. „Językoznawcy wobec badań języka w Internecie”. Artes Humanae 1: 111-124.

Kobierecka, A. 2012. „Emocjonalny aspekt obrazu ciała a ocena relacji z rodzicami u młodych kobiet”. Przegląd Psychologiczny 55 (4): 383-395.

Kubat, K. 2012. „Problem jadłowstrętu psychicznego w polskich podręcznikach psychiatrii (1845-2003) i jego kulturowe odniesienia”. W $W$ zdrowiu $i$ w chorobie... Z badań antropologii medycznej i dyscyplin pokrewnych, red. D. Penkala-Gawęcka, I. Main, i A. Witeska-Młynarczyk. Poznań: Biblioteka Telgte Wydawnictwo, 133-150.

Laskowska-Otwinowska, J. 2012. „Historyczno-kulturowe uwarunkowania koncepcji zdrowego odżywiania”. W $W$ zdrowiu $i$ w chorobie... Z badań antropologii medycznej i dyscyplin pokrewnych, red. D. Penkala-Gawęcka, I. Main, i A. Witeska-Młynarczyk. Poznań: Biblioteka Telgte Wydawnictwo, 119-131.

Ogonowska, A., i B. Skowronek. 2005. „JJęzyk na nielegalu», czyli wpływ multimediów na komunikację werbalną młodego pokolenia. O nową metodologię badań”. W Język@multimedia, red. A. Dytman-Stasieńko, i J. Stasieńko. Wrocław: Wydawnictwo Naukowe Dolnośląskiej Szkoły Wyższej Edukacji TWP, 297-309.

Olejnik, K. 2005. „Wspólnoty w sieci”. W: Umyst - ciało-sieć, red. E. Stawowczyk-Tsalawoura, i W. Chyła. Poznań: Wydawnictwo Naukowe UAM, 221-236.

Piekot, T. 2008. Język w grupie społecznej. Wprowadzenie do analizy socjolektu. Wałbrzych: Wydawnictwo Państwowej Wyższej Szkoły Zawodowej im. Angelusa Silesiusa.

Rudnicki, S. 2013. Ciało i tożsamość w internecie. Teoria, dyskurs, codzienność. Warszawa: Wydawnictwo Naukowe Scholar.

Seniów, A. 2018. „O konstrukcjach typu anoreksja, anorektyk, anorektyczka we współczesnej polszczyźnie”. Studia Językoznawcze. Synchroniczne i diachroniczne aspekty badań polszczyzny 17: 291-302.

Shilling, C. 2019. Socjologia ciała. tłum. M. Skowrońska. Warszawa: Wydawnictwo Naukowe PWN. 
Skowronek, B. 2012. „Jedzenie jako tekst kultury. Zarys problemu”. Annales Universitatis Paedagogicae Cracoviensis Studia Historicolitteraria 12: 281-289.

Skowronek, B. 2013. Mediolingwistyka. Wprowadzenie. Kraków: Wydawnictwo Naukowe Uniwersytetu Pedagogicznego.

Smoleń-Wawrzusiszyn, M. 2016. „Socjolekty wirtualne - metody lingwistyki a komunikacja językowa w społecznościach sieciowych”. W Metody badań online, red. P. Siuda. Gdańsk: Wydawnictwo Naukowe Katedra, 182-234.

Strzelecki, W. i in. 2010. „Przegląd serwisów internetowych zawierających treści pro- i antyzdrowotne w kontekście zaburzeń odżywiania”. Zeszyty Naukowe Uniwersytetu Szczecińskiego. Studia Informatica 25: 155-173.

Szews, P. 2013. „Mikroblog - odmiana blogu czy oddzielny gatunek?”. Acta Universitatis Lodziensis Folia Litteraria Polonica 2 (20): 271-289.

Talarczyk, M., i K. Nitsch. 2010. „Zaburzenia odżywiania się w portalach internetowych - opis i analiza zjawiska”. Psychoterapia 1 (152): 67-80.

Teler, A. 2021. „Wykorzystanie fenomenu anty-body shaming do (re)interpretacji obrazu ciała na Instagramie”. Annales Universitatis Paedagogicae Cracoviensis Studia de Cultura 13 (1): 103-123.

Wiatrowska, A. 2013. „Poczucie koherencji dziewcząt z anoreksją i bulimią psychiczną”. Lubelski Rocznik Pedagogiczny 32: 276-294.

Wilk, E. 2007. „Dyskurs kultury - dyskurs języka. O ważnej tendencji badań kulturoznawczych”. Kultura Wspótczesna 1: 56-67.

Wronka, M., i M. Jezierska-Kazberuk. 2011. „Świat porcelanowych motyli. Blogi internetowe o tematyce odchudzającej jako źródło informacji o zaburzeniach odżywiania”. Forum Zaburzeń Metabolicznych 2 (2): 102-112.

Ziółkowska, B., red. 2009. Opętanie (nie)jedzeniem. Warszawa: Wydawnictwo Naukowe Scholar.

\title{
Body on the Web - (Cyber)world of People with Eating Disorders in the Context of Somatic Discourse
}

Keywords: somatic discourse, eating disorders, ED, sociology of the body, sociolect.

\begin{abstract}
The subject of the discussion is the linguistic image of the body in people with eating disorders (ED) who communicate via the Internet. The analysis concerns the language and style of blogs and microblogs written in 2012-2020 by people (mostly young women) identifying with the pro-Ana and pro-Mia movements. The most important transformations taking place in this cyber-community were indicated, including the transition from somatic exclusion, through body neutrality, to body acceptance. Leanness, even excessive leanness, is now often interpreted in this context not as a disorder (disease), but as a synonym for a healthy, responsible lifestyle. The purpose of the analysis, apart from updating the findings of linguists and researchers representing other disciplines (especially psychologists and sociologists writing about eating disorders), was to recreate the relationship between the medial (constructed) and perceived body image (resulting from self-exclusion practices) and to observe the linguistic mechanisms that build and maintain a sense of
\end{abstract}


community among people with ED spectrum. In discussing these issues, the author combines a linguistic approach with findings in the field of cultural studies and sociology, with particular emphasis on research in the field of sociology of the body. The subject of observation are lexical and onimic contexts in which the attitude of people with eating disorders to the body is visible, especially in the aspect of its fragmentation and transformation. These findings are part of a broader context related to the interpenetration of (contradictory) discourses: diet discourse and the so-called body positivity (anty-body shaming), i.e. accepting your natural body. 